\title{
Olympic and post-olympic slum: demographic and real estate market dynamics at the Vidigal slum*
}

\author{
Favela olímpica e pós-olímpica: dinâmicas \\ demográficas e no mercado imobiliário do Vidigal
}

Nayana Corrêa Bonamichi [l]

\begin{abstract}
In this article, we analyze the new demographic and real estate dynamics established in the Vidigal slum, Rio de Janeiro, within what we call here the olympic (2007-2016) and post-olympic periods (2016-2018). Based on a systematic probability sample of semi-structured questionnaires administered to 364 households, we analyzed the impacts of this period on the socioeconomic profile of this slum population and on the local real estate market, assessing whether these impacts remained or not after the end of the mega-event period. As a result, we show the formation of a new migration flow towards this slum after its pacification, a flow that shows signs of retraction after the end of the mega-event period.
\end{abstract}

Keywords: slums; mega-events; demographic dynamics; real estate dynamics; gentrification.

\section{Resumo}

Neste artigo, lançamos um olhar atualizado sobre as novas dinâmicas demográficas e imobiliárias instauradas na favela do Vidigal, Rio de Janeiro, dentro do que chamamos aqui de período olímpico (2007-2016) e pós-olímpico (2016-2018). Apoiados em uma amostra probabilistica sistemática de questionários semiestruturados aplicados a 364 domicílios, analisamos os impactos desse período no perfil socioeconômico da população dessa favela e no mercado imobiliário local, avaliando em que medida esses impactos permaneceram ou não após o fim do período de megaeventos. Como resultado, apontamos para a formação de um novo fluxo migratório em direção a essa favela após a sua pacificação, fluxo este que apresenta sinais de retração após o fim do período de megaeventos.

Palavras-chave: favelas.; megaeventos; dinâmicas demográficas; dinâmicas imobiliárias; gentrificação. 


\section{Introduction}

In recent years, few subjects have been so debated in Rio de Janeiro urban studies as the impacts of the period we will call here "the mega-events decade". ${ }^{1}$ Public and private investments resources to prepare the "Rio host city" were mainly concentrated in the fields of urban mobility and public security (Santos Junior, Gaffney and Ribeiro, 2015). No less important, the revitalization of Rio de Janeiro port area is also part of the set of urban restructuring policies to prepare the city for this period. The "Porto Maravilha" project is inserted in a worldwide movement of port areas requalification.

In regard to housing, some informal lowincome territories were impacted in this period mainly by two fronts of public policies: first, by the removal of a portion of these territories due to the resumption of removal practices by the municipal government ${ }^{2}$ and, second, by the indirect impacts effects that occurred due to the improvement in public safety indices in part of the territories that received the Pacifying Police Unit (UPP) program.

The slums pacification program was officially launched in 2008 by the State Secretariat for Public Security and its first unit was the Santa Marta UPP, implemented in the Santa Marta slum, in the south zone of Rio de Janeiro city. With the announcement that the city of Rio de Janeiro would host the 2016 Olympic Games, the slum pacification program became one of the pillars of the city's preparation project to host the imminent sports mega-event.
The short and medium-term impacts of the implementation of the first Pacifying Police Unit on pacified territories were widely debated in many research fields. ${ }^{3}$ What these studies have shown is that the beginning of the first UPPs implementation was marked by an unprecedented increase in property prices located in and around the pacified slums just a few days after the implementation of these units (Mandel and Frischtak, 2012). Added to this, the increased presence of higher-income groups in the surrounding regions or within some pacified slums was widely reported not only by academic papers, but also by the local press (Tadini, 2013; Cummings, 2013; Quirion, 2017; Novaes, 2017). Some studies indicate that this migratory movement was mainly due to the attractiveness of improvements in public safety (Mandel and Frischtak, 2012; Tadini, 2013), while others point out that one of the main factors that marked this dynamic was also the desire to move for an "authentic community" (Tadini, 2013; Cummings, 2013; Quirion, 2017).

In an attempt to explain the contradictions and complexities of demographic phenomena observed in some of the pacified slums during the mega-event period, some concepts such as "neo-favelados" (Quirion, 2017, p. 22) and "peripheral gentrification" (Novaes, 2017, p. 202), were used by researchers to typify what would be the new residents who began to be attracted to settle in some Rio de Janeiro slums during the international events period. ${ }^{4}$

Despite this, the absence of more indepth empirical work brings some limitations to the understanding of the demographic 
phenomena that were actually established in these territories. Added to this, the lack of an updated look at these dynamics after the end of the so-called mega-events decade, prevents us from evaluating if these phenomena persist or not after this period. For this reason, a better understanding of the phenomena that have taken shape in these spaces in recent years requires an expanded and updated look at these territories.

\section{Methodological notes}

Conducting a research to help us understand the demographic dynamics that marked the mega-events decade period in some Rio de Janeiro slums presents us with a challenge: knowing the socioeconomic profile and demographic characteristics of the population that lived in these spaces before the studied period and that one who started to live in these places in mega-events period.

To assess these dynamics, we selected the Vidigal ${ }^{5}$ slum as a case study for this research. One of the factors that helps us to justify this choice is the intense inflation in real estate prices that this slum experienced in the period after the installation of UPP Vidigal - Chácara do Céu, in 2012. This UPP made Vidigal one of the areas with the highest price appreciation of its properties throughout the city of Rio de Janeiro in the period 20082015 (Bonamichi, 2016). In our view, the high inflation experienced by local property prices is a strong indication of the intensification of new demographic dynamics and in the local property market in the studied period.

The survey covered different qualitative and quantitative methodological strategies. In the quantitative part of this research, we collected data on the local resident's socioeconomic profile. In the qualitative part, we conducted semi-structured interviews with residents and local leaders. Quantitative data collection was performed using statistical sampling techniques. From a systematic probabilistic sample of households, part of the target population was interviewed so that the results were representative for the entire territory. In total, 364 local households were interviewed. The reference period for the collected information is from august 1 st to october 30th, 2018.

The script developed for the questionnaires applied to the households sample was structured to obtain data on the socioeconomic profile of the population, always considering how long they lived in this space. In this way, the profile of more recent residents could be compared to the profile of older residents. We collected information such as income, place of birth, length of residence in the place, education, migratory flows and perceptions about the place. 


\section{Olympic Period (2012-2016): comparative analysis of the socioeconomic profile of pre- and post-pacification residents}

In this section, we present some demographic indicators that aim to characterize the profile of the population residing in the area studied by this research. The comparative analysis of these indicators will help us to understand the differences between the average socioeconomic profile of the population that already lived in this space before the study period of this research and of the population that started living in the most recent period.

What we obtained from the data collected was a portrait of a population formed mainly by people who have been in this territory for only a generation, predominantly composed of migrants from other states in the country (of which the strong presence of northeastern migrants stands out). It is also about a population that migrated towards this slum motivated by work-related issues, but the prior existence of family members networks and acquaintances was essential for the choice to move specifically to this location. Added to this, it is a population with a low level of education, having color and race relatively evenly divided between whites and blacks or browns and with an average income that is mainly concentrated in the range of 0 to 2 minimum wages and average income household income of about 3 minimum wages. ${ }^{6}$
The survey of primary data on the socioeconomic profile of the population residing in the studied area, based on a representative sample of its residents, allowed us to compare characteristics of different groups in this population. Thus, establishing the length of residence of the respondent as the main variable, it was possible to compare data on birthplace, household income, color/ race, education, among others, of residents who started to live in this space in the more recent period and from residents who have lived in this place for a longer time.

For Vidigal, we established the 2012 timeframe, the year of installation of the Vidigal Pacification Police Unit, ${ }^{7}$ and compared the average profile of the population that already lived on this slum in the prepacification period and that which started to migrate towards to that location in the post-pacification period. Later, we repeated the same analysis by inserting another time frame: 2016, the year in which the so-called mega-events decade ends, with the end of Rio de Janeiro Olympic Games. Below, we present the results of this comparative analysis.

The comparison of place of birth data of residents who already lived in this place before the pacification and those who started living in the post-2012 period shows us that, at the same time that there is a drop of $29 \%$ in the participation of interstate migrants among the more recent residents, there is an $16 \%$ increase of residents from other neighborhoods in the municipality of Rio de Janeiro, $6 \%$ among those from cities in the Rio de Janeiro state or metropolitan region, and $5 \%$ among those from foreign countries (Graph 1). 
Graph 1 - Households naturality according to their housing time in Vidigal

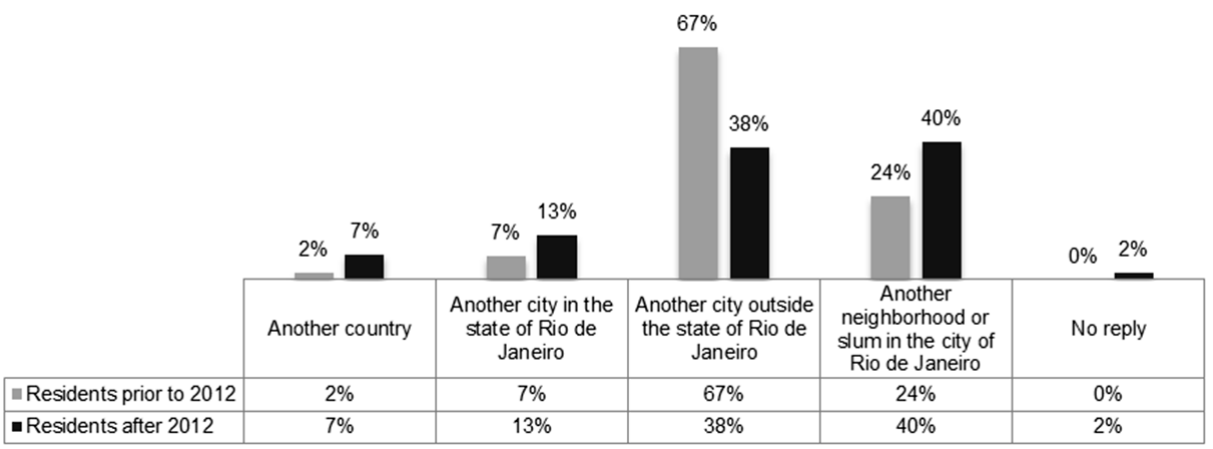

Source: estimates produced based on the household sample surveyed by this research.

The evaluation of the migrants' last place of residence before moving to Vidigal allows us to understand the residential mobility of families residing in these spaces and helps us to formulate an origin matrix of this population. The analysis of possible changes in this matrix in recent years can help us to identify the formation of new migratory flows to these spaces in the recent period. Therefore, we asked those responsible for the interviewed households who were not born in the area in question their last place of residence before moving to the studied slum. Once again, the comparison of these data, considering the groups of residents who already lived in Vidigal before its pacification and those who started living after this period, shows us that there is a drop in the relative participation of migrants from other states in the country. If among older residents this percentage was $46 \%$, it goes to $20 \%$ among new residents. We also observe that the relative weight of those coming from other formal neighborhoods in the city towards Vidigal increases, going from 34 to $44 \%$, and those coming from other slums in the city rises from 10 to $16 \%$. The percentage of residents coming from other cities in the state or metropolitan region of Rio de Janeiro, in turn, goes from 10 to $20 \%$ (Graph 2).

The analysis of migratory flows is complemented by the question that investigated the motivations behind the formation of these flows towards the studied area. When asked about the reasons that made them specifically look for Vidigal as a place of residence, the interviewees answered freely. Subsequently, through the use of 
Graph 2 - Last place of residence according to how long they live in Vidigal

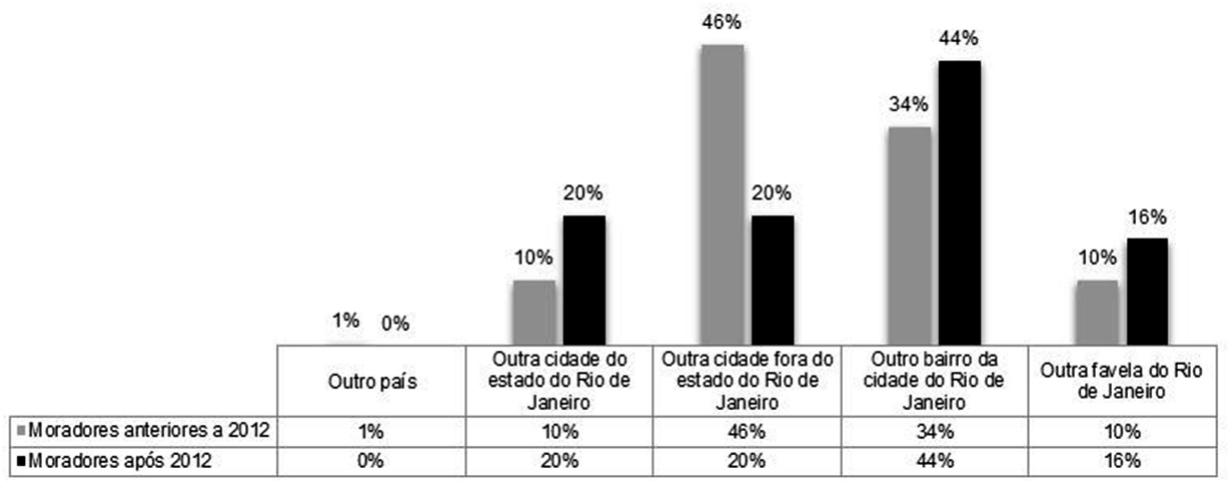

Source: estimates produced based on the household sample surveyed by this research.

content analysis techniques, the answers were grouped into seven categories (prior presence of family members on the slum, price, work, location, safety, personal well-being or other). It is important to point out that, for this analysis, the first reason cited by the respondent for specifically choosing Vidigal as their place of residence was considered. From this, we realize that, although the choice for this specific slum was motivated by issues such as the search for work or the locational advantages of this slum, most of the interviewees specifically chose this slum motivated primarily by family issues.

Among residents who already lived in Vidigal in the pre-2012 period, we see that the factors most cited as reasons for moving to this place were the "previous presence of family members in this slum" (55\%) and "work" (14\%). These migrants are less guided by the reasons "price" (4\%) and "location" (5\%). When we look at the migrants who came to live in Vidigal in the period after pacification, although those who came to this place motivated by family issues still predominate, we observe that there was an increase in those who came to live there motivated by issues such as work (24\%), price $(15 \%)$, location (9\%) and safety (7\%) and a reduction in those who sought the slum motivated by the previous presence of family members in this place (29\%) (Graph 3).

The main difference when we look at the data regarding the education of residents who already lived in Vidigal in the pre-pacification period and those who started to look for the slum as a place of residence after this period is the percentage of residents with incomplete primary education, higher education (complete and incomplete) and postgraduate studies. While $38 \%$ of the former residents had incomplete primary education, only $11 \%$ of the new post-pacification residents had this level of education. Likewise, while only $13 \%$ of the residents who already lived in this place before the pacification had completed, incomplete or post-graduated higher education, $37 \%$ of the new residents had at least started an undergraduate degree (Graph 4). 
Graph 3 - Reasons for moving to Vidigal according to how long they have lived there

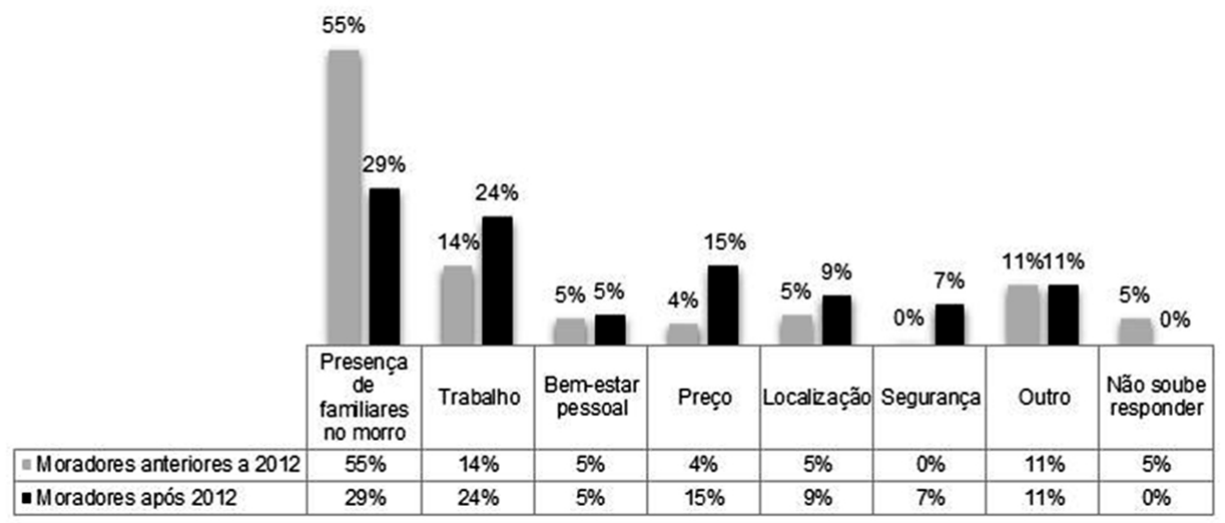

Source: estimates produced based on the household sample surveyed by this research.

Graph 4 - Schooling according to length of residence in Vidigal

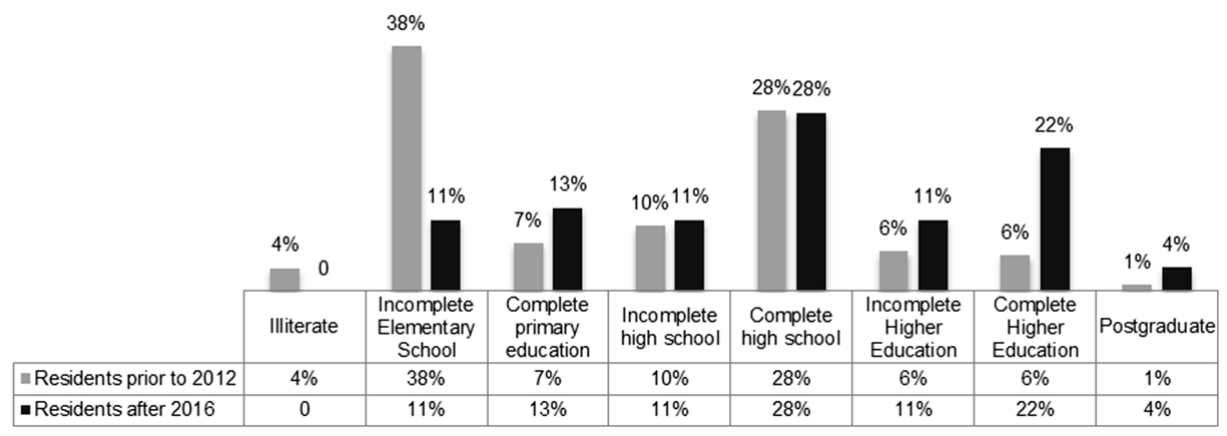

Source: estimates produced based on the household sample surveyed by this research. 
Regarding to color and race, our survey shows that the population that started to look for Vidigal as a home in the period after the local pacification is $62 \%$ white and $36 \%$ black or brown. In other words, it is a population $20 \%$ whiter and $21 \%$ less black and brown than the one who already lived in that place (Graph 5).

The average household income of all households interviewed in this survey was $R \$ 2,695.58$ on the date of the survey. When we isolate only the households that were already occupied before the local pacification, this average income drops to $\mathrm{R} \$ 2,355.03$. Furthermore, when we isolate the households that started to be occupied after the local pacification, we see that the average household income becomes $R \$ 3,613.80$. The difference in average household income between households already occupied before pacification and those that were occupied after this process is $\mathrm{R} \$ 1,258.77$, which corresponds to 1.32 minimum wages, considering the value of $R \$ 954,00$, the Brazilian minimum wage in force on the date of this survey in Vidigal (Graph 6).

The comparative analysis of the data regarding the socioeconomic profile of the population that already lived in Vidigal in the pre-pacification period and that that started to migrate towards that place after this period shows us that, while the population that already lived in the place was predominantly black or brown (57\%), with education level mainly concentrated between incomplete elementary and high school (66\%) and coming mainly from other states in the country $(46 \%)$, what characterizes the profile of the population that started to live in this space after the installation of the UPP, in February 2012 , is the fact that it is predominantly white (62\%), with a significantly higher average individual and household income, a higher rate of education and postgraduate studies and the last place of residence mainly concentrated

Graph 5 - Color or race according to length of residence in Vidigal

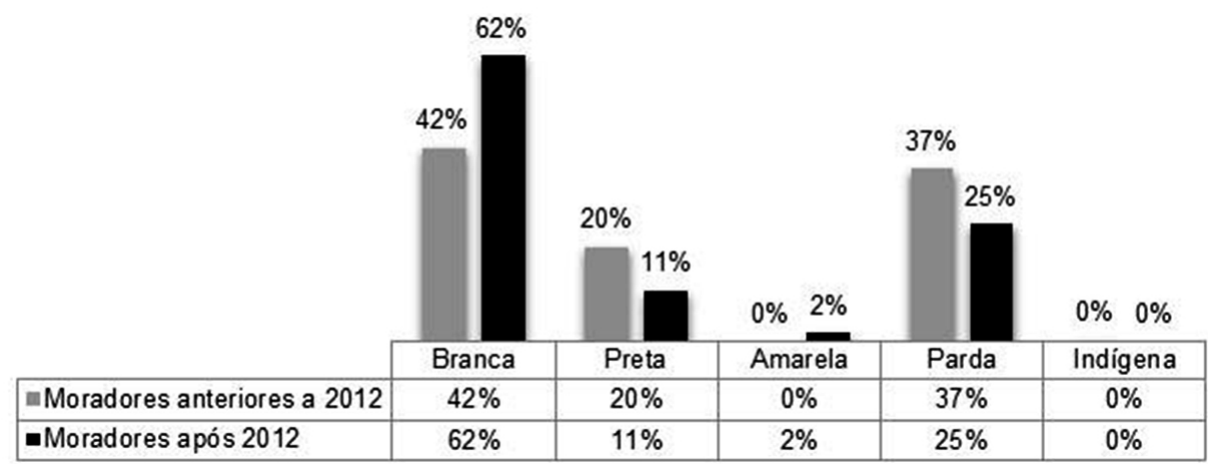

Source: estimates produced based on the household sample surveyed by this research. 
Graph 6 - Average household income according to the length of residence in Vidigal

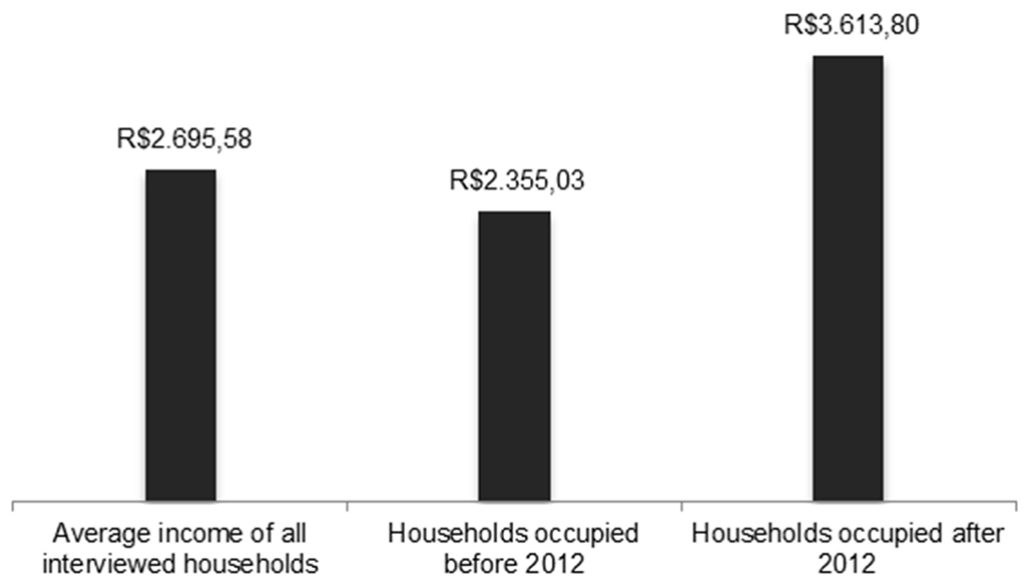

Source: estimates produced based on the household sample surveyed by this research.

in other formal neighborhoods in the city of Rio de Janeiro (44\%). This comparative analysis shows us an important change in the socioeconomic profile of the groups that started to migrate towards Vidigal after the local pacification when compared to the average profile of those who already lived in this slum before this period.

The analysis of data on the last place of residence among residents who already lived in this place before the pacification and those who started living after it points to the intensification of migratory flows from other formal neighborhoods in the city and from other cities in the state of Rio de Janeiro (notably from the metropolitan region) and the regression of migratory flows from other states in the country. This indicates that the installation of UPP Vidigal may have made Vidigal a housing possibility for new social groups other than those who had historically migrated towards this slum in the search for housing before our research time frame.

\section{Post-Olympic Period (2016-2018): demographic dynamics reorganization?}

In the previous topic, we showed that residents who started to look for Vidigal as a place of residence after the implementation of the local UPP have some profile differences in aspects such as color/race, education, income and last place of residence when compared to 
residents who already lived in Vidigal before this period. However, if we further deepen the analysis of the data collected by our research separating the migrant residents who already lived in Vidigal in the pre-2012 period, those who started to live in the four-years period following the pacification (2012-2016) and those who started living in the most recent period (2016-2018), we again observed some divergences in the socioeconomic profile between these three groups of migrants.

The comparison of color and race data of the population that already lived in Vidigal in the pre-pacification period and that that started to look for this slum as a place of residence after this period showed us that migrants who moved to Vidigal in the most recent period are whiter and less black and brown than the average of the population that already lived in that space before this period. In addition, when we further fragmented this data, inserting the new 2016 timeframe, what we realized is that those who move to Vidigal in the post-2016 period have a color and race profile more similar to the average of the population that was already living on this place before its pacification. While the migrants who moved to this place in the period 2012-2016 are $75 \%$ white and $23 \%$ black or brown, the migrants heading to Vidigal in the period 20162018 are $55 \%$ white and $45 \%$ black or brown, a profile closer to the residents who had been living since before the pacification ( $48 \%$ white and $51 \%$ black or brown).

The analysis of data on the average monthly nominal income of respondents also points to a significantly higher average income among those who moved to Vidigal in the period 2012-2016 (R\$1,683.95) and a lower average income among those who moved to
Vidigal in the post-2016 period ( $R \$ 1,341.00)$. Again, when we look at those who have moved in the last two years (2016-2018), the average monthly nominal income is closer to the average monthly nominal income of residents who already lived in this space in the prepacification period (R\$1,391.64).

When we look at the education level of migrants who go to Vidigal considering the same timeframes 2012 and 2016, what we observe is that residents who move to Vidigal in the 2012-2016 period have a higher level of education than the average of the residents who already lived in this place before the pacification. While $87 \%$ of residents who already lived in Vidigal before pacification had completed high school and $13 \%$ had started or completed higher education, only $58 \%$ of residents who moved to Vidigal in the 2012-2016 period had completed high school while $43 \%$ had started or completed higher education. Among residents who started to migrate in the most recent period (2016-2018), the percentage of residents who had started or completed higher education dropped again (33\%) and those who had completed high school increased (64\%).

We were able to better observe what appears to be the formation of a new migratory flow when we assess the last place of residence of these migrants before moving to Vidigal. There is a drastic increase in the participation of migrants who previously lived in other formal neighborhoods in the city of Rio de Janeiro among those who started to look for Vidigal as a place of residence in the four years following the local pacification (2012-2016). While only $34 \%$ of those who moved to Vidigal in the pre-pacification period came from other formal neighborhoods and $46 \%$ came 
from cities outside the state, among those who moved to this slum from 2012 to 2016, $70 \%$ came from other formal neighborhoods and $15 \%$ from cities outside the state. Among those who moved to Vidigal in the post-2016 period, however, the participation of residents coming from other formal neighborhoods drops again (30\%) while the participation of those coming from other cities in the state of Rio rises (24\%), from outside the state (24\%) and from other slums (a percentage that goes from 0\% among migrants from 2012 to 2016 to $21 \%$ among migrants who moved in the period 2016-2018).

When we evaluated the reasons that made those who migrated towards Vidigal choose this slum as their place of residence, what we noticed is a significant difference in motivation between those who moved to this location in the pre-2012, 2012-2016 and post-2016 period. While residents who already lived in the place before pacification chose Vidigal as their home much more motivated by issues such as the previous presence of family members in this slum (55\%), those who started to look for it to live in the period 2012-2016 are less motivated by family reasons (19\%) and more motivated by the cost-benefit relation, which involves items such as price (29\%), location (14\%), safety (10\%) and personal wellbeing (5\%). In the post-2016 period, however, we noticed a resumption of those migrants who started to look to Vidigal as a place of residence driven by family issues (36\%) and work (30\%) and a reduction in those motivated by issues such as price $(6 \%)$, location (6\%) and security (6\%).

What we can see with these data is that over the four years that followed the local pacification (2012-2016), a new rental housing market began to take place in Vidigal, attracting residents from different areas of Rio de Janeiro. These residents have a different socioeconomic profile from the average of the local population. Furthermore, this new observed migratory flow seems to lose strength in the period we call here the post-Olympic period (2016-2018).

Vidigal saw the local trafficking command (previously belonging to the ADA - Amigos dos Amigos) being replaced by the Comando Vermelho (CV) at the end of $2017 .^{8}$ With the change of command and the weakening of the UPPs, Vidigal returned to live the drama of daily armed clashes between police officers and groups linked to drug trafficking. At the same time, the deep crisis that began to affect the model of territorial control exercised by the Pacifying Police Units intensified from the second half of 2017 , when $33 \%$ of the police force that occupied posts in pacified slums was relocated out of these spaces. From then on, successive resources cuts and changes in the UPPs' operating model reinforced the narrative of the model's failure. Thus, there was an intensification of repression by the effective that still operated in pacified slums and the gradual return of the presence of ostensibly armed groups linked to drug trafficking to these territories.

The public security crisis in Rio de Janeiro, the drug trafficking control change in Vidigal, the end of sporting mega-events and the brazilian political-economic crisis, which intensifies mainly in the post-2015 period, are some of the factors that may have contributed for a reorganization of the new demographic and economic dynamics observed in Vidigal in the period 2012-2016. 


\section{Real estate dynamics: new formats}

Vidigal has a percentage of rented properties almost $10 \%$ above the average of rented properties located in precarious settlements in the municipality of Rio de Janeiro. ${ }^{9}$ As a result, it has a percentage of property owners almost $10 \%$ below the average of property owners located in precarious settlements in the municipality. These numbers show the existence of a relatively stronger residential property rental market in Vidigal when compared to the average for other slums in Rio de Janeiro.

In this type of territory, occupied following what Abramo (2000) calls the "logic of need", it is quite common the household fractionation to divide the same building as the family expands. Thus, we have buildings for multifamily use (where more than one family nucleus lives) and that have some kinship relationship with each other (extended families: parents and children, grandparents and grandchildren, uncles and nephews, etc.). In addition, a type of fragmentation that is increasingly common in these spaces has been the one that transforms previously single-family buildings into multi-family ones, occupied by people who have no kinship relationship with the family that previously lived in that property. This type of fractioning occurs when the owner intends to rent or sell part of the building, leading to a condition of cohabitation between people who do not have any kinship relationship with each other.

The predominant type of use in Vidigal's buildings can vary according to its location. Along Presidente João Goulart avenue, the main access road that cuts across the hill and goes from the lower part to the top of the slum, it is very common to have mixed-use properties, with commercial spaces on the ground floor and owned or rented houses on the upper floors. In the other areas of Vidigal, buildings for strictly residential use are more common, but which house more than one domicile. These households are occupied either by people who have some kinship relationship with each other (extended families) and sometimes by groups that have no family relationship with each other.

When we compare the percentage of single-family, multi-family buildings occupied by people with some relationship between them and multi-family occupied by people with no relationship to each other, what we notice is a decrease of the percentage of buildings occupied by more than one household where there are people with some degree of kinship among themselves (22\% among the properties occupied before the pacification and $7 \%$ among the properties occupied after this period). On the other hand, there is an increase on the percentage of buildings with more than one household occupied by people with no relationship between each other (33\% among properties occupied before pacification and $49 \%$ among properties occupied after pacification).

Likewise, we noticed some small differences in the building typologies occupied by those who already lived in Vidigal in the pre-pacification period and those who started living in the more recent period. We noticed that the percentage of residents living in studio apartments is slightly higher $(15 \%$ among post-pacification residents versus $7 \%$ among previous residents), hostels/pensions 
(4\% among post-pacification residents versus $0 \%$ among previous residents) or apartments located in buildings with more than four floors (9\% among post-UPP residents and 5\% among pre-UPP residents). Meanwhile, it reduced the percentage of people living in houses with only one floor ( $29 \%$ of residents who already lived in Vidigal before the pacification and $18 \%$ of those who started to live after) and those living in buildings of up to four floors $(60 \%$ among older residents and 51\% among new residents).

The multifamily residential property model with a monthly payment rental format starts to share space with other rental formats, which began to be more common after pacification and the increase in demand for housing or temporary stay on Vidigal. Many residents also start to rent rooms from their homes on a daily or seasonal basis and transform their homes into hostels with shared rooms in an attempt to increase their income with the new demand that emerges in the post-pacification period.

In 2010, only three hostels or guesthouses ${ }^{10}$ establishments were operating in Vidigal. In April 2012, three months after the installation of the local UPP, six establishments of this type were surveyed in the slum. In december 2014, this number was already 23, remaining close to that until january 2017, possibly as a reflection of the 2016 postOlympics period. In august 2018, in turn, only 12 of these establishments still in operation on Vidigal. ${ }^{11} \mathrm{~A}$ survey on the characterization of these accommodation establishments carried out by us shows that $69 \%$ of these establishments were initially residences that were adapted or expanded to function as accommodation. Another $23 \%$ of these properties were built to function as a hostel and $8 \%$ were commercial points that were adapted for this use.

We observed significant differences between the occupation condition of the properties by those who already lived in Vidigal before 2012 and those who started to live there after this period. While $20 \%$ of those who lived there before 2012 lived on rented houses, this rate rises to $81 \%$ when we analyze the residents who started to live there after that period. These data indicate that the Vidigal real estate market followed a trend also seen in other Rio de Janeiro slums. ${ }^{12}$

The rental contract model between tenants and owners of rented residential properties is essentially verbal in Vidigal, repeating a pattern also found in other Rio de Janeiro slums (Abramo, 2020). The rate of residential properties rented without any type of written contract or using only the practice of the so-called "verbal contract" is $76 \%$ of residential properties rented in this location.

The flexibility of a property rental market whose contract model is predominantly verbal enables access to housing for those who live in a precarious professional condition in informal jobs. What can be seen as a precarious form of contractual relationship between tenants and owners is often what guarantees the access of certain social groups to rental housing. The predominance of this essentially verbal format of the lease in these spaces plays an important role in guaranteeing access to housing for these groups, while guaranteeing them the possibility of migrating from one property to another, adapting at any time to the possible unforeseen reductions in their families' household income. 
It should be noted that Vidigal has internal differences in terms of urban infrastructure, housing precariousness, safety and accessibility, and these differences are quite complex. Our data show that not only does Vidigal have a higher percentage of rented properties than the average of properties located in precarious settlements in the city of Rio de Janeiro, but also that tenants of rented residential properties in this area move a lot from one property to another within the slum. Among the residents who lived on rent in Vidigal, $62 \%$ had already lived on rent in more than one different property within that same slum. Among these, $41 \%$ had already lived in at least three or four different properties within Vidigal. Nine percent of local tenants had already lived in more than five different properties in that same slum. This migratory movement inside the same slum is facilitated by the conditions in verbal rental contracts.

It is interesting to note that $32 \%$ of rented residential properties whose residents were interviewed for this survey had owners who lived outside Vidigal at the time of the survey. This indicates that there is a relevant number of residential properties for rent that are explored by people from outside Vidigal. If building in these slums can be a well-located housing alternative for many of these owners, keeping a rental property in these spaces can also guarantee an income and the departure of these people from Vidigal, with their return to their hometowns or moving to other areas of Rio of January. Owning your own property, which for a long time was a way of guaranteeing livelihoods for part of the local population, is now also an investment with high financial returns for this layer of the population.
Researches investigating the impacts of UPPs on the real estate market in pacified areas indicated that the growth in rental contracts was the most important impact of the installation of these units on the informal real estate market in pacified slums (Abramo, 2020). The strong increase in the prices of real estate transactions in these places after receiving the implementation of an UPP was one of the characteristics of a new phenomenon in these slums: a growing population with a temporary occupation condition and less security in their possession condition.

The increase in the offer of properties for informal rental in these spaces has intensified processes of verticalization and houses fractioning, promoting what Abramo (2020) called the "precariousness of the precarious". What our study shows is that, in Vidigal, there was in fact an intense intraslum migratory movement mainly motivated by the constant increases in rent prices. This migratory movement is only possible due to the size of slums such as Vidigal and their own internal socio-spatial inequalities, which make their sub-regions have a large variation in rent prices between them.

What our research also showed is that, in addition to a strong dynamism in the local property rental market, an intense intra-slum migratory flow and cases of expulsion of residents pressured by high prices in local properties, the most relevant movement observed was the intensification of a migratory flow formed by groups with a different socioeconomic profile from the average of the local population that, attracted by the improvement in the conditions of security, price and locational advantages, thicken the already dense informal market 
for rental properties in this slum. There is a greater participation of people from other formal neighborhoods of the city and the metropolitan region when compared to the average population that already lived in Vidigal in the prior pacification period (which came mainly from other states in the country). The new flow formed by residents coming from the formal neighborhoods of the city is possibly also a consequence of the pressure caused by the rise in rent prices in places where these groups previously lived. This population then began to see in Vidigal favorable housing conditions after its pacification.

The end of the first and the beginning of the second decade of the 21st century are marked by a strong heating of the brazilian real estate market on a national scale. From January 2010 to March 2012, calculations performed based on the FipeZap index indicate a variation of $43 \%$ in the average sale price of real estate in Brazil (Ipea, 2012, p. 7). In the same period, among the metropolitan areas studied, Rio de Janeiro showed the greatest variation in these prices, with an increase of $168 \%$ in the average value of property sales (Ipea, 2012). Some factors such as the drop in interest rates, the expansion of credit directed to the real estate sector, the heating up of the job market and the rise in the national average income helps to explain the rise in real estate prices on a national scale during this period. In Rio de Janeiro, the factors mentioned above were also added to the moment of preparation of this city to host major world scale events, which led to an increase in investments, mainly in road infrastructure and in public safety policies in the mentioned period and a consequent overvaluation of properties that where directly or indirectly benefited from these investments.

That is, if in the time frame period of this research we experienced a generalized process of inflation in real estate prices on a national scale, the city of Rio de Janeiro experienced, in the same period, a double process of inflation in its average purchase prices, real estate sales and rental. The slums that started to receive investments under the pacification program with the installation of new Pacifying Police Units in their territories, then experienced an even more intense process of increase in the prices of their properties. In an analysis based on data from the Institute of Economic Research Foundation (Fipe) and ZAP Imóveis (Fipe/ ZAP index) in Bonamichi (2016) we show that Vidigal had an increase of over $500 \%$ in the average sale price of their properties in the period 2008-2015. With regard to rental prices, between february 2010 and september 2015 , there was an increase of around $370 \%$ in the average price of properties rented in this location, a percentage much higher than in other formal neighborhoods in the city. In july 2015, the average rental price (in $\mathrm{R} \$$ per $\mathrm{m}^{2}$ ) in Vidigal was comparable to that of neighborhoods such as Copacabana, Leme, Urca and Jardim Botânico (Bonamichi, 2016).

Despite already having a very dynamic real estate market before the pacification process, the insecurity generated by the presence of armed groups linked to drug trafficking in areas such as Vidigal repressed part of the potential of the local real estate market. With the installation of the UPP, 
Vidigal then supply an existing demand for well-located housing and relatively low prices in the southern zone of the Rio de Janeiro city. The benefits of factors such as proximity to jobs, price and safety became more evident after the installation of pacification units in these spaces and opened a new exploration frontier for an already existing demand for well-located housing at low prices.

Some works that focused on the same theme of this research pointed to the formation of a new migratory flow towards the pacified slums during the period of mega-events. These flows are formed by groups with higher purchasing power and are generally inserted in a movement that Janoschka (2009) calls "lifestyle mobility" ${ }^{13}$ or described by Quirion (2017) as "neo-favelados". Works such as those by Quirion (2017) and Novaes (2017) shed light on a migratory movement formed by groups of high purchasing power towards some pacified Rio de Janeiro slums in a phenomenon similar to what has been historically described as a gentrification process.

The concept of gentrification was first used by the British sociologist Ruth Glass to characterize a phenomenon of substitution of working-class groups by middle- and upper-class groups in London's low-income neighborhoods. Since then, gentrification, which derives from the English gentry - from "lower nobility" - has become synonymous with spatial elitization. In other words, it is an urban colonization movement carried out by segments of the upper middle class that produce impacts in popular areas through the purchase or rental of local properties for residential purposes.
With our research data, we show that the migratory flows formed by the groups described above were a quantitatively less representative movement given the complexity of the new demographic dynamics that began to take shape with the pacification of these territories. The most relevant migratory flow, according to the data obtained by us, seems to be a quantitatively more representative movement formed by a mass of workers with slightly higher purchasing power, whiter, more educated, coming from areas different from those that predominated among migrants who went to Vidigal before its pacification and motivated by issues that differ from the average of local residents. This group now occupies the growing universe of rental properties available in Vidigal.

What differentiates this second movement observed in our research from the first movement observed by most of the researches that focused on the Rio de Janeiro slums in the period of sporting mega-events is that what we observed was a migratory movement formed by groups that, pressured also by the increase of the real estate market prices in the neighborhoods where they used to live, began to see in Vidigal a new possibility of housing in view of the improvement in the safety indices in that location. Unlike a movement of "lifestyle mobility", it is a population with income only slightly above the average of the population that already lived in this space and that starts to migrate to this place motivated by more practical issues, such as the cost-benefit ratio between location, security and price, which are now offered after local pacification. 
The post-2016 period, however, is marked at the same time by a retraction in the dynamism of the local real estate market and by the resumption of migratory flows formed by a population whose socioeconomic profile is closer to that of those who already lived in this slum before its pacification. This indicates that, if what we are calling here the Olympic period - the period between local pacification (2012) and the end of the so-called megaevents decade (2016) - is marked by the formation of new demographic dynamics in the studied slum, what we call here the postOlympic period (post-2016) is marked by a retraction of this process.

\section{Final considerations}

With the data resulting from this research, we add new elements to the debate about the impacts of the mega-events period on demographic dynamics and on the real estate market of the pacified Rio de Janeiro slums. At the same time, we update this debate by taking a look at what we call here the post-Olympic period (post-2016), in which we assess the continuity or retraction of phenomenas that started in the previous period.

In Vidigal, the installation of UPP leads to the formation of new demographic dynamics in this space. Our comparative analysis of socioeconomic profile of the population that already lived in this place before the installation of the UPP and the profile of the population that began to live in this space after its pacification indicates some differences between these two population groups in terms of color/race, education, place of birth, last place of residence, average monthly household income and reasons that led these people to move to this slum. A more fragmented analysis shows us that this change in profile occurs mainly among those who moved to Vidigal in the four years after the installation of UPP Vidigal (2012-2016) but not among those who moved to live in this slum in the most recent years, here called "post-Olympic" period (2016-2018).

When we analyze the profile of the population that started to live in this place in the period 2012-2016 and compared it to the profile of the population that already lived in this space before that period, we note that the population that started to migrate to Vidigal after its pacification is whiter, with a higher level of education, mainly from the city of Rio de Janeiro or the metropolitan region, has an average household income significantly higher than the average income of the older population and who migrated towards Vidigal very motivated mainly for reasons related to price, work and security than the population that lived in this place before.

In addition, the population that already lived in Vidigal before the pacification is more black and brown, with a lower level of education, with a high percentage of interstate migrants coming mainly from the Northeast region of Brazil, with lower household income and who sought housing in the Vidigal motivated mainly by questions related to family issues. Among the population that started living in Vidigal in the post-2016 period (20162018), we noticed a socioeconomic profile 
much closer to the average of the population that already lived in this place before the pacification than to the population that started to live there in the period 2012-2016.

These data indicate that the installation of UPP Vidigal is now attracting a type of migratory flow that was previously less present in this slum. The pacification leads to hyperinflation in the prices for buying, selling and renting real estate in the area and helps to restrict access to the local real estate market by population groups that previously occupied that space. The pacification of Vidigal means that this place starts to attract new population layers and to meet demands that were previously repressed for welllocated housing and relatively low prices in the southern zone of the Rio de Janeiro city. The benefits of factors such as proximity to jobs, price and safety became more evident after the installation of pacification units in these spaces, an action that opened a new exploration frontier for the real estate market.

The retaking of territories dominated by armed groups linked to drug trafficking by the State through the implementation of the Pacifying Police Units meant the opening of new housing possibilities for some social groups at the same time that the increase in the cost of living in these pacified communities restricted their access to groups who were previously able to pay for housing in these locations. In other words, there is a restriction of certain migratory flows at the same time that new flows are formed towards slums such as Vidigal. Ultimately, this is a population group that also pressured by the rise in rental and purchase and sale values of properties in other areas of the city is now joining the already dynamic informal rental market in pacified areas such as Vidigal in the search for a better cost-benefit ratio between location, price and security.

In addition, the public security crisis in Rio de Janeiro, the change of command of the local drug traffic, the end of sporting mega-events and the brazilian politicaleconomic crisis, which intensifies mainly in the post-2015 period, are some of the factors that have contributed to what we consider to be a (re)organization of socioeconomic and spatial transformation processes that began in the four-year period following the local pacification.

\section{[I] https://orcid.org/0000-0001-8922-2678}

Universidade de São Paulo, Faculdade de Arquitetura e Urbanismo, Programa de Pós-Graduação em Arquitetura e Urbanismo. São Paulo, SP/Brasil.

mnbona@gmail.com

Translation: this article was translated from Portuguese to English by the author herself. 


\section{Notes}

$(*)$ This study was financed in part by the Coordenação de Aperfeiçoamento de Pessoal de Nível Superior - Brasil (CAPES) - Finance Code 001.

(1) For nearly a decade (2007-2016), the city of Rio de Janeiro hosted a series of large-scale events including: 2007 Pan American Games, FifaFanFest (2010), Rio+20 (2012), World Youth Day and Confederations Cup (2013), 2014 World Cup and 2016 Olympic Games.

(2) Magalhães (2012) shows how the "Rio host city" period is marked by a reconstruction of removalist discourses and practices in a strategy to relegitimize the slums removal as a practice and as a political program by the municipal government. Azevedo and Faulhaber $(2015$, p. 36) show that, from January 2009 to December 2013, more than 20 thousand families were removed from their homes, which would correspond to about 67 thousand people. It is more than double of people removed during the Carlos Lacerda government (about 30.000 people between 1961 and 1965) and more than three times those removed during the Pereira Passos period $(20.000$ between 1902 and 1906).

(3) For the UPPs impacts on the real estate market in and around pacified areas, see Mandel and Frischtak (2012); for the impacts on the commercial dynamics of pacified areas: IETS (2012); and for the UPPs impacts in public safety indicators: Cano, Borges and Ribeiro (2012).

(4) With "neofavelados" term, Quirion (2017) tries to typify what would be the new residents who began to be attracted to settle in some Rio de Janeiro slums during the international events period. What characterizes and motivates these groups to seek residency in these spaces, according to the researcher, is not only the financial issue, but mainly "the desire to integrate into a social dynamic perceived as different: more "human" and "authentic"”. In Novaes (2017), the term "peripheral gentrification" appears as an attempt to characterize a process of punctual elitization of some specific areas of Rio's slums, while these territories remain popular and stigmatized by marginality.

(5) With the first records of occupation dating from the 1940s, Vidigal slum is located between two of the most elite neighborhoods in the city of Rio de Janeiro: Leblon and São Conrado. According to the 2010 brazilian Census, Vidigal had, in that year, a population of 12.797 inhabitants and 4.585 households. Historically, it occupies an emblematic position among the Rio de Janeiro slums due to its history of resistance against removal attempts by the state government in the 1970s. Also during this period, it came to be recognized as the "artists' hill", for being a place of residence for groups linked to music and theater and for the presence of the theater group "Nós do Morro". In recent years, it received the status of "favela chic" due to the intensification of the migration movement of famous groups linked to the arts and the increase in the number of entertainment tourism establishments, which began to attract visitors from greater purchasing power for this location.

(6) Reference values $\mathrm{R} \$ 954.00$, brazilian minimum wage in force in the second half of 2018.

(7) Vidigal was the 19th area to receive an UPP, on January 18, 2012.

(8) What characterized the ADA (Amigos dos Amigos) command was mainly a more subtle and discreet presence while the $\mathrm{CV}$ (Comando Vermelho) is known for its more ostensible territorial domain and for the violence characteristic of this group. 
(9) According to the 2010 brazilian Census, $20.8 \%$ of the properties located in precarious settlements in the municipality of Rio de Janeiro were in a condition of rent occupation while $75.3 \%$ were owned. At Vidigal, we found a percentage of rented properties of $29.4 \%$ and a percentage of owned properties of $65.4 \%$.

(10) A guesthouse is an accommodation characterized as a "low cost hotel", often a private house converted. A hostel is a type of accommodation characterized by low prices and socialization among guests, who can be accommodated in private or shared rooms. At Vidigal, we verified the existence of a very heterogeneous range of accommodation establishments. These are establishments characterized as affordable alternative accommodation, with private or shared rooms, divided by gender or not, comunal kitchen and shared bathroom.

(11) These data are from the mapping "Vidigal 100 Segredos" and from research carried out by the author.

(12) Research developed by Abramo (2020) points out that, from 2002 to 2011, there is a constant growth in the relative share of rental transactions when compared to the number of property purchase and sale transactions in this type of popular settlement. During this period, the percentage of rental transactions in slums rose from $48 \%$ to $79 \%$.

(13) The concept of "lifestyle mobility" was created by Janoschka to characterize seasonal or temporary migratory movements, usually formed by young people who temporarily migrate towards countries or territories culturally distinct from their homeland, with the intention of living authentic experiences.

\section{References}

ABRAMO, P. (2020). A nova informalidade urbana e o mercado informal de aluguéis. In: SEMINÁRIO INTERNACIONAL MORADIA DE ALUGUEL NA AMÉRICA LATINA. Palestra de Encerramento. São Paulo, LabCidade, Faculdade de Arquitetura e Urbanismo da USP. Disponível em: https://www. youtube.com/watch?v=w0tIS28SuF8\&t=3016s. Acesso em: 20 out 2020.

AZEVEDO, L.; FAULHABER, L. (2015). SMH 2016: Remoções no Rio de Janeiro Olímpico. Rio de Janeiro, Morula Editorial.

BONAMICHI, N. C. (2016). Favela on sale: regularização fundiária e gentrificação de favelas no Rio de Janeiro. Dissertação de mestrado. Rio de Janeiro, Universidade Federal do Rio de Janeiro.

(2020). Favela olímpica e pós-olímpica: um olhar atualizado sobre as dinâmicas comerciais e turísticas no Vidigal no período 2012-2018. Revista E-Metropolis. Rio de Janeiro, v. 1, n. 40, pp. 25-33.

CANO, I.; BORGES, D.; RIBEIRO, E. (orgs.) (2012). Os Donos do morro: uma avaliação exploratória do impacto das Unidades de Polícia Pacificadora (UPPS) no Rio de Janeiro. São Paulo, Fórum Brasileiro de Segurança Pública; Rio de Janeiro, Lav/UERJ.

CUMMINGS, J. (2013). Confronting the favela chic: gentrification of informal settlements in Rio de Janeiro, Brazil. Dissertação de mestrado. Cambridge, Harvard University. 
IETS (2012). Pesquisa sobre Microempreendedorismo em domicílios nas favelas com Unidades de Polícia Pacificadora. Rio de Janeiro. Relatório de pesquisa.

IPEA (2012). Existe bolha no mercado imobiliário brasileiro? São Paulo. Textos para discussão.

JANOSCHKA, M. (2009). The contested spaces of lifestyle mobilities: regime analysis as a tool to study political claims in latin american retirement destinations. Die Erde. Berlim, n. 140, pp. 1-20.

MAGALHÃES, A. (2012). Entre o legal e o extralegal: A reatualização da remoção de favelas no Rio de Janeiro. Revista Brasileira de Estudos Urbanos e Regionais. Rio de Janeiro, v. 14, n. 1, pp. 119-133.

MANDEL, B. R.; FRISCHTAK, C. (2012). Crime, house prices and inequality: the effects of UPPs in Rio. Rio de Janeiro, Federal Reserve Bank of New York. Staff Report n. 542.

NOVAES, P. R. (2017). A gentrificação periférica na cidade do Rio de Janeiro: um estudo sobre as favelas Babilônia, Chapéu Mangueira, Vidigal e Santa Marta. Tese de doutorado. Rio de Janeiro, Universidade Federal do Rio de Janeiro.

QUIRION, N. (2017). Jogos de distinção e lógica da exclusão: problematizando o conceito de gentrificação a partir de uma favela urbanizada do Rio de Janeiro. Revista E-Metropolis. Rio de Janeiro, v. 31, pp. 22-30.

SANTOS JUNIOR, O. A.; GAFFNEY, C.; RIBEIRO, L. C. de Q. (orgs.) (2015). Brasil: os impactos da Copa do Mundo 2014 e das Olimpíadas 2016. Rio de Janeiro, 1. ed. - E-papers.

TADINI, N. (2013). Chasing the real: the gentrification of Rio de Janeiro's favelas. Dissertação de mestrado. Roskilde, Roskilde University. 
